\title{
HUBUNGAN PELAYANAN KEPERAWATAN DENGAN KEPUASAN PASIEN RAWAT INAP DI RSUD BANGKINANG KOTA TAHUN 2019
}

\author{
Nany Librianty \\ Program Studi Sarjana Keperawatan Universitas Pahlawan Tuanku Tambusai \\ nanilibrianti@ rocketmail.com
}

\begin{abstract}
Abstrak
Pelayanan dari semua upaya yang dilakukan karyawan untuk memenuhi keinginan pelanggannya dengan jasa yang akan diberikan. Kepuasan pasien merupakan nilai subyektif terhadap kualitas pelayanan yang diberikan walaupun subyektif tetap ada dasar obyektifnya. Menurut data di RSUD Bangkinang Kota jumlah pasien tahun 2014 sebanyak sebanyak 5480 orang, jumlah pasien tahun 2015 sebanyak 6340 orang. Dari tahun 2014 sampai tahun 2015 terlihat adanya peningkatan jumlah pasien rawat inap. Namun ada 10 orang yang tidak merasakan kepuasan pelayanan. Tujuan penelitian untuk menganalisa hubungan pelayanan keperawatan dengan kepuasan pasien rawat inap. Desain penelitian ini adalah survey analitik. Populasi pada penelitian ini semua pasien berobat dirawat inap di RSUD Bangkinang Kota tahun 2016. Teknik pengambilan sampel adalah accidental sampling yaitu sebanyak 95 orang yang dirawat inap. Waktu penelitian di lakukan pada tanggal 6-8 September tahun 2016. Alat ukur yang digunakan adalah lembar kuesioner. Analisa yang digunakan univariat dan bivariat, diolah dengan menggunakan sistem komputerisasi dan uji-chi square. Hasil penelitian ini menunjukkan bahwa terdapat hubungan yang signifikan antara pelayanan keperawatan nilai $\mathrm{p}=$ 0,001 dengan kepuasan pasien rawat inap. Diharapkan hasil penelitian ini dapat dijadikan masukan bagi tenaga kesehatan RSUD Bangkinang Kota dengan dengan meningkatkan mutu pelayanan keperawatan di RSUD Bangkinang Kota.
\end{abstract}

Daftar Bacaan : 27 (2000 - 2014).

Kata Kunci : Pelayanan Keperawatan dan Kepuasan Pasien Rawat Inap.

@ Jurnal Ners Prodi Sarjana Keperawatan \& Profesi Ners FIK UP 2019

$\square$ Corresponding author :

Address : Jl. Tuanku Tambusai No. 23 Bangkinang

Email : nanilibrianti@rocketmail.com

Phone : 081277712797 


\section{PENDAHULUAN}

Didalam Sistem Kesehatan Nasional disebutkan bahwa "Pembangunan kesehatan pada hakekatnya adalah penyelenggaraan upaya kesehatan oleh bangsa Indonesia untuk mencapai kemajuan hidup sehat bagi setiap penduduk agar dapat mewujudkan derajat kesehatan masyarakat yang optimal" (Depkes RI 2009).

Blum (1974), mengatakan: untuk dapat meningkatkan derajat kesehatan masyarakat, banyak hal yang perlu dilakukan. Salah satu diantaranya yang dipandang mempunyai peranan yang cukup penting ialah menyelenggarakan pelayanan kesehatan. Adapun yang dimaksud dengan pelayanan kesehatan ialah setiap upaya yang diselenggarakan secara sendiri ataupun bersama-sama dalam satu organisasi untuk memelihara dan meningkatkan kesehatan, mencegah dan menyembuhkan penyakit serta memulihkan kesehatan perseorangan, keluarga kelompok dan ataupun masyarakat.

Agar pelayanan kesehatan masyarakat dapat mencapai tujuan yang diinginkan, banyak syarat yang harus dipenuhi. Syarat yang dimaksud paling tidak mencakup delapan hal pokok yang tersedia (available), wajar (appropriate), berkesinambungan (continue), dapat diterima (acceptable), dapat dicapai (accessible), dapat dijangkau (affordable), efisien (efficient) dan bermutu (quality). Kedelapan syarat pelayanan kesehatan ini sama pentingnya. Namun pada akhirakhir ini, dengan semakin majunya ilmu pengetahuan dan teknologi kedokteran maka semakin baik pula tingkat pendidikan serta keadaan sosial ekonomi masyarakat, dimana kebutuhan dan tuntutan akan pelayananan kesehatan masyarakat semakin meningkat (Widiyo Ertanto, 2002).

Sedangkan kepuasan pasien tergantung pada kualitas pelayanan. Pelayanan adalah semua upaya yang dilakukan karyawan untuk memenuhi keinginan pelanggannya dengan jasa yang akan diberikan. Suatu pelayanan dikatakan baik oleh pasien, ditentukan oleh kenyataan apakah jasa yang diberikan bisa memenuhi kebutuhan pasien, dengan menggunakan persepsi pasien tentang pelayanan yang diterima (memuaskan atau mengecewakan, juga termasuk lamanya waktu pelayanan).

Kepuasan dimulai dari penerimaan terhadap pasien dari pertama kali datang, sampai pasien meninggalkan rumah sakit. Pelayanan dibentuk berdasarkan 5 prinsip Service Quality yaitu kecepatan, ketepatan, keramahan dan kenyamanan layanan ( Wike, 2009).

Berkaitan dengan penyelenggaraan pelayanan kesehatan, Rumah sakit merupakan salah satu bentuk organisasi penyelenggara pelayanan kesehatan. Rumah sakit memberikan pelayanan kesehatan yang komprehensif mencakup semua aspek promotif, preventif, kuratif, dan rehabilitatif bagi seluruh lapisan masyarakat. Oleh karena itu pelayanan di rumah sakit seringkali mengalami permasalahan yang mencakup tentang ketidakpuasan masyarakat terhadap mutu pelayanan dirawat inap dan rawat jalan yang dianggap kurang memadai atau memuaskan (Azwar 1996).

Sedangkan rumah sakit mempunyai tugas melaksanakan upaya kesehatan secara berdayaguna dan berhasilguna dengan mengutamakan upaya penyembuhan dan pemulihan yang dilaksankan secara serasi dan pencegahan serta melaksanakan upaya rujukan (Depkes RI). Setiap rumah sakit dituntut harus dan mampu mewujudkan pelayanan yang efisien, efektif dan bermutu secara paripurna serta berorientasi pada kepuasan pasien.

Adapun salah satu upaya yang dapat dilakukan demi memenangkan persaingan ini adalah dengan memberikan pelayanan yang berkualitas melalui peningkatan sarana, fasilitas serta sumber daya manusia(Wiyono dkk, 2006).

Rumah sakit dinyatakan berhasil, tidaknya hanya pada kelengkapan fasilitas yang diunggulkan, selain itu sikap dan pelayanan kesehatan yang di berikan pada pasien juga berpengaruh terhadap pelayanan. Bila pelayanan kesehatan tersebut diabaikan maka, rumah sakit akan kehilangan banyak pasien dan dijauhi oleh calon pasien. Pasien akan beralih ke rumah sakit lainnya yangmemenuhi harapan pasien, hal 
tersebut dikarenakan pasien merupakan hal yang paling berpengaruh dalam mengembangkan industri rumah sakit.

Menurut (Purwanto,2007 dalam Kunaefi 2012) bahwa rumah sakit dianggap baik apabila dalam pelayanan lebih memperhatikan kebutuhan pasien maupun keluarga pasien yang berkunjung ke rumah sakit. Kepuasan muncul dari kesan pertama pasien masuk rumah sakit, misalnya: pelayanan yang cepat, tanggap dan keramahan dalam memberikan pelayanan keperawatan (Triwibowo, C 2012).

Pelayanan dalam hal ini adalah pelayanan kesehatan yang diterima oleh pasien. Kebutuhan pasien terhadap layanan kesehatan yang semakin kompleks akan menuntut pelayanan kesehatan yang profesional dalam mengatasi masalah kesehatan. Salah satu pelayanan kesehatan yang ada di Indonesia adalah pelayanan keperawatan. Pelayanan keperawatan memiliki peranan yang penting dalam pelaksanaan pelayanan kesehatan di rumah sakit dimana secara keseluruhan terutama rumah sakit.

Jumlah tenaga perawat merupakan tenaga paling banyak bila dibandingkan dengan tenaga kesehatan lainnya, sehingga perannya menjadi penentu dalam pelayanan kesehatan baik di rumah sakit maupun di puskesmas. Selain itu, perawat lebih banyak berinteraksi dengan pasien selama 24 jam untuk melaksanakan layanan keperawatan. Keberhasilan pelayanan rumah sakit sangat tergantung pada kinerja perawat rumah sakit dalam melaksanakan layanan keperawatan di rumah sakit (Asmuji ,2013).

Tuntutan masyarakat atas pelayanan keperawatan yang semakin meningkat membuat perawat sebagai profesi mempunyai andil dan tanggung jawab besar dalam memberikan pelayanan keperawatan yang berkualitas. Dalam tataran pelayanan kesehatan dipuskesmas dan di rumah sakit, perawat menjadi kunci keberhasilan dalam menyelenggarakan pelayanan kesehatan. Perawat mempunyai kontribusi yang sangat besar dalam tataran tersebut (Asmuji, 2013).

Kepuasan pasien merupakan nilai subyektif terhadap kualitas pelayanan yang diberikan walaupun subyektif tetap ada dasar objektifnya, artinya walaupun penilaian itu dilandasi oleh hal : pengalaman masa lalu pasien, pendidikan pasien, situasi psikhis waktu itu dan pengaruh lingkungan waktu itu (Dr.dr.H. Boy S. Sabarguna, MARS, 2008). Kepuasan pasien pada dasarnya memuaskan pasien dengan harapan dan memahami kebutuhan pasien. Pasien lama yang berkunjung kembali ke rumah sakit dapat mempengaruhi kualitas pelayanan kesehatan(Raheem, et al, 2014)

Pasien dikatakan puas jika pelayanan yang diterima oleh pasien sesuai dengan harapan pasien atau melampaui harapan yang pasien inginkan dan jika pelayanan yang diterima oleh pasien tidak sesuai harapan maka sebaliknya pasien tidak puas (Ehsan, et al, 2014).

Hasil awal wawancara peneliti dengan salah satu pegawai di RSUD Bangkinang Kota pada bulan Maret tahun 2016, hasil yang diperoleh peneliti bahwa layanan keperawatan belum dilakukan secara maksimal. Hal tersebut bisa dilihat dari masih banyaknya pasien yang komplain akan layanan keperawatan di rumah sakit dimana pasien masih belum puas akan pelayanan yang didapat, pasien komplain melalui message ke salah satu pegawai rumah sakit bagian pelayanan keperawatan. Akan tetapi pegawai sering kali mengabaikan komplain dari pasien tersebut dan untuk survei kepuasan pelanggan di Rumah Sakit Umum Daerah Ungaran Kabupaten Semarang tidak dilakukan secara berkala.

Selain dibuktikan dari hasil wawancara, data jumlah pasien rawat inapjuga menggambarkan kepuasan pasien. Jumlah pasien rawat inap dari tahun 2014-2015. Jumlah pasien tahun 2014 sebanyak 5480 orang, jumlah pasien tahun 2015 sebanyak 6340 orang. Dari tahun 2014 sampai tahun 2015 terlihat adanya peningkatan jumlah pasien rawat inap. Namun ada 10 orang yang tidak merasakan kepuasan pelayanan.

Dari 124 orang perawat, 43 orang diantaranya perawat rawat inap sedangkan 14 orang adalah perawat IGD. Jumlah tenaga perawat rawat inap berdasarkan jenjang pendidikan dapat dilihat ditabel di bawah ini : 


\begin{tabular}{|l|c|c|}
\hline \multicolumn{1}{|c|}{ Jabatan } & Pendidikan & Jumlah \\
\hline $\begin{array}{l}\text { Kepala } \\
\text { Perawat }\end{array}$ & S1 (Ners) & 3 orang \\
\hline Kepala Ruang & S1 (Ners) & 3 orang \\
\hline Staf Perawat & Akper/D3 & 1 orang \\
\hline Staf Perawat & Akper/D3 & 38 orang \\
\hline \multicolumn{1}{|c|}{ Total } & & 43 orang \\
\hline
\end{tabular}

Sumber: Profil RSUD Bangkinang Kota

Dimana rumah sakit umum daerah milik pemerintah daerah kabupaten semarang yang mempunyai tugas melaksanakan upaya pelayanan kesehatan secara berdaya guna dan berhasil guna dengan mengutamakan upaya penyembuhan (kuratif), pemulihan (rehabilitatif) yang dilaksanakan secara serasi dan terpandu mempertimbangkan pelayanan yang efektif, efisien, serta professional.

Selain itu peneliti juga melakukan studi pendahuluan dimana peneliti observasi dan wawancara secara langsung kepada pasien dengan kriteria pasien opname selama dua hari. Wawancaranya yaitu mengenai pelayanan keperawatan di rumah sakit: aspek perhatian, aspek penerimaan, aspek komunikasi, aspek kerjasama dan aspek tanggungjawab. Hasil yang diperoleh peneliti bahwa.

pelayanan keperawatan belum dilakukan secara maksimal. Hal tersebut dapat terlihat dari hasil studi pendahuluan pada pasien rawat inap di Rumah Sakit Umum Daerah (RSUD) Bangkinang Kota Kabupaten Kampar melalui 25 pasien rawat inap mengeluhkan belum puas terhadap pelayanan perawatan yang ada di rumah sakit. Sebanyak 52\% pasien mengeluh pada aspek perhatian, 72\% pasien mengeluh pada aspek penerimaan, $76 \%$ pasien mengeluh pada aspek komunikasi,60\% mengeluh pada aspek kerjasama, dan $64 \%$ pasien mengeluh pada aspek tanggung jawab.

\section{METODE PENELITIAN}

Penelitian ini merupakan penelitian Survey Analitik dengan pendekatan Cross Sectional. Artinya penelitian ini dilakukan untuk melihat hubungan variabel indenpenden dan variabel denpenden yang pengambilan data dilakukan pada saat yang bersamaan (Notoatmodjo, 2010).

Penelitian ini dilaksanakan pada rawat inap di RSUD Bangkinang Kota. Waktu penelitian dilaksanakan pada tanggal $6-8$ September 2016.Populasi adalah keseluruhan subjek penelitian. Popilasi adalah setiap objek yang memenuhi kriteria yang telah diterapkan (Nursalam, 2008). Populasi dalam penelitian ini adalah semua pasien berobat dirawat inap di RSUD Bangkinang.sampel yamh di teliti sebanyak 95 orang.Sebagian sampel dalam penelitian ini adalah pasien yang dirawat inap di RSUD Bangkinang Kota pada saat penelitian selama hari. Kriteria sampel terdiri dari kriteria eksklusi. Pasien yang dirawat di RSUD Bangkinang Kota yang berumur 14 tahun keatas berkeadaan umum sadar pada saat penelitian. Teknik sampling yang digunakan dalam penelitian ini adalah Accidental Sampling. Pengolahan Data ini dilakukan dengan diolah secara manual dengan komputerisasi, setelah data terkumpul

\section{HASIL PENELITIAN}

Penelitian ini dilakukan pada tanggal $6-8$ September tahun 2016. Di RSUD Bangkinang Kota Tahun 2016. Responden penelitian ada sebanyak 95 responden. Data yang diambil pada penelitian ini yaitu pelayanan keperawatan (variabel independen) dan kepuasan pasien (variabel dependen). Dari penyebaran kuesioner telah peneliti lakukan maka didapatkan hasil sebagai berikut. 


\section{A. Analisa Univariat}

Tabel 4.1 Frekuensi Responden Berdasarkan Umur di RSUD Bangkinang Kota Tahun 2016

\begin{tabular}{cccc}
\hline No & Usia & F & $(\%)$ \\
\hline 1 & $20-30$ & 24 & 25,3 \\
2 & $31-40$ & 32 & 33,7 \\
$\mathbf{3}$ & $\mathbf{4 1 - 5 5}$ & $\mathbf{3 9}$ & $\mathbf{3 6}$ \\
\hline & Jumlah & 95 & 100 \\
\hline
\end{tabular}

\section{Sumber : Penyebaran Kuesioner}

Dari tabel 4.1 dapat dilihat bahwa dari 95 responden sebagian besar umur responden 41-55 yaitu sebanyak 39 orang (36\%).

Tabel 4.2 Frekuensi Responden Berdasarkan Pendidikan Terakhir di RSUD Bangkinang Kota Tahun 2016

\begin{tabular}{cccc}
\hline No & Pendidikan terakhir & f & $(\boldsymbol{\%})$ \\
\hline 1 & SD & 5 & 5,3 \\
$\mathbf{2}$ & SLTP & $\mathbf{3 9}$ & $\mathbf{4 1}$ \\
3 & SMA & 36 & 37,9 \\
4 & Perguruan Tinggi & 15 & 15,8 \\
& & & \\
\hline & Jumlah & 95 & 100 \\
\hline
\end{tabular}

\section{Sumber : Penyebaran Kuesioner}

Dari tabel 4.2 dapat dilihat bahwa dari 95 responden sebagian besar pendidikan terakhir responden SLTP yaitu sebanyak 39 orang (41\%)

Tabel 4.3 Frekuensi Responden Berdasarkan Jenis Kelamin di RSUD Bangkinang Kota Tahun 2016

\begin{tabular}{cccc}
\hline No & Jenis Kelamin & f & $\mathbf{( \% )}$ \\
\hline 1 & Laki-laki & 43 & 45,3 \\
$\mathbf{2}$ & Perempuan & $\mathbf{5 2}$ & $\mathbf{5 4 , 7}$ \\
\hline & Jumlah & 95 & 100 \\
\hline
\end{tabular}

Sumber : Penyebaran Kuesioner
Dari tabel 4.3 dapat dilihat bahwa dari 95 responden sebagian besar jenis kelamin responden perempuan yaitu sebanyak 52 orang $(54,7 \%)$.

Tabel 4.4 Frekuensi Responden Berdasarkan Pekerjaan di RSUDBangkinang Kota Tahun 2016

\begin{tabular}{cccc}
\hline No & Pekerjaan & f & $(\boldsymbol{\%})$ \\
\hline $\mathbf{1}$ & IRT & $\mathbf{2 7}$ & $\mathbf{2 8 , 4}$ \\
2 & Petani & 15 & 15,8 \\
3 & Buruh & 10 & 11 \\
4 & PNS & 17 & 17.9 \\
5 & Pegawai Swasta & 26 & 21,9 \\
\hline & Jumlah & 95 & 100 \\
\hline
\end{tabular}

\section{Sumber : Penyebaran Kuesioner}

Dari tabel 4.4 dapat dilihat bahwa dari 95 responden sebagian besar pekerjaan responden IRT yaitu sebanyak 27 orang $(28,4 \%)$.

\section{B. Analisa Bivariat}

Analisa univarate terdiri dari pelayanan keperawatan dan kepuasan pasien. Hasil analisa dapat dilihat pada tabel berikut :

Tabel 4.5 Frekuensi Responden Berdasarkan Pelayanan Keperawatan diRSUD Bangkinang Kota Tahun 2016

\begin{tabular}{ccc}
\hline $\begin{array}{c}\text { pelayanan } \\
\text { keperawatan }\end{array}$ & f & $\mathbf{( \% )}$ \\
\hline Baik & 41 & 43,2 \\
Kurang & $\mathbf{5 4}$ & $\mathbf{5 6 , 8}$ \\
Jumlah & & 100 \\
\hline
\end{tabular}

\section{Sumber : Penyebaran Kuesioner}

Dari tabel 4.5 dapat dilihat bahwa dari 95 responden sebagian pelayanan keperawatan responden kurang yaitu sebanyak 54 orang $(56,8 \%)$. 
Tabel 4.6 Frekuensi Responden Berdasarkan Kepuasan Pasien di RSUD Bangkinang Kota Tahun 2016

\begin{tabular}{|c|c|c|c|}
\hline No & Kepuasan Pasien & f & $(\%)$ \\
\hline 1 & Puas & 38 & 40 \\
\hline 2 & Tidak puas & 57 & 60 \\
\hline & Jumlah & 95 & 100 \\
\hline
\end{tabular}

Dari tabel 4.6 dapat dilihat bahwa kepuasan pasien pada pelayanan keperawatan di RSUD Bangkinang Kota sebagian besar tidak puas yaitu 57 responden $(60 \%)$.

\section{Analisa Bivariate}

\section{Hubungan Pelayanan Keperawatan dengan Tingkat Kepuasan Pasien Rawat Inap di RSUD Bangkinang Kota Tahun 2016. \\ Untuk mengetahui hubungan pelayanan keperawatan dengan tingkat kepuasan pasien rawat inap, penulis sajikan dalam bentuk tabel dibawah ini.}

Tabel 4.7 Hubungan Pelayanan Keperawatan dengan Tingkat Kepuasan Pasien Rawat Inap di RSUD Bangkinang Kota Tahun 2016

\begin{tabular}{|c|c|c|c|c|c|c|c|c|}
\hline \multirow{3}{*}{$\begin{array}{l}\text { Pelayan } \\
\text { an } \\
\text { Kepera } \\
\text { watan }\end{array}$} & \multicolumn{4}{|c|}{$\begin{array}{c}\text { Kepuasan } \\
\text { Pasien }\end{array}$} & \multicolumn{2}{|c|}{ Total } & \multirow{3}{*}{$\begin{array}{l}\quad \mathbf{P} \\
\text { Va } \\
\text { lu } \\
\text { e }\end{array}$} & \multirow{3}{*}{$\begin{array}{l}\mathbf{P} \\
\mathbf{O} \\
\mathbf{R} \\
\mathbf{9 5 \%} \\
\mathbf{C I}\end{array}$} \\
\hline & \multicolumn{2}{|c|}{$\begin{array}{c}\text { Tidak } \\
\text { Puas } \\
\end{array}$} & \multicolumn{2}{|c|}{ Puas } & \multirow[b]{2}{*}{$\mathbf{N}$} & \multirow[b]{2}{*}{$\%$} & & \\
\hline & $\mathbf{N}$ & $\%$ & $\mathbf{N}$ & $\%$ & & & & \\
\hline Kurang & 40 & 74,1 & 14 & 25,9 & 54 & 100 & & \\
\hline Baik & 17 & 41,5 & 24 & 58,5 & 41 & 100 & 0,001 & $\begin{array}{l}4.035 \\
(1.69- \\
9.625)\end{array}$ \\
\hline Jumlah & 57 & 60 & 38 & 40 & 95 & 100 & & \\
\hline
\end{tabular}

Sumber : Penyebaran Kuesioner 2016

Berdasarkan tabel 4.7 dapat dilihat bahwa dari 54 responden (100\%) dengan pelayanan keperawatan kurang yang puas yaitu sebanyak 14 responden $(25,9 \%)$ sedangkan dari 41 responden $(100 \%)$ dengan pelayanan keperawatan baik yaitu yang tidak puas sebanyak 17 responden $(41,5 \%)$.
Berdasarkan uji statistik diperoleh nilai $\mathrm{p}=0,001$ ( $\mathrm{P}$ value < 0,05), sehingga Ho ditolak, dengan demikian secara statistik terdapat hubungan antara pelayanan keperawatan dengan tingkat kepuasan pasien rawat inap. Dengan Prevalance Odds Ratio $(\mathrm{POR})=4.035(95 \% \mathrm{CI}=1.690-9.625)$. Hal ini menunjukkan bahwa responden yang pelayanan keperawatan kurang mempunyai peluang sebesar 4.035 kali tidak puas dibandingkan dengan responden yang pelayanan keperawatan baik.

\section{PEMBAHASAN}

Berdasarkan hasil penelitian yang telah dilakukan peneliti tentang hubungan pelayanan keperawatan dengan tingkat kepuasan pasien rawat inapdi RSUD Bangkinang Kota Tahun 2016 untuk selanjutnya di lakukan pembahasan sebagai berikut:

1. Hubungan Pelayanan Keperawatan dengan Tingkat Kepuasan Pasien Rawat Inap di RSUD Bangkinang Kota Tahun 2016.

Dari hasil penelitian dapat dilihat bahwa dari 54 responden $(100 \%)$ dengan pelayanan keperawatan kurang yang puas yaitu sebanyak 14 responden $(25,9 \%)$ sedangkan dari 41 responden (100\%) dengan pelayanan keperawatan baik yaitu yang tidak puas sebanyak 17 responden $(41,5 \%)$. Berdasarkan uji statistik diperoleh nilai $\mathrm{p}=0,001$ ( $\mathrm{P}$ value < 0,05), sehingga Ho ditolak, dengan demikian secara statistik ada hubungan antara pelayanan keperawatan dengan tingkat kepuasan pasien rawat inap. Dengan POR $=4.035(95 \% \mathrm{CI}=$ 1.690-9.625). Hal ini menunjukkan bahwa responden yang pelayanan keperawatan kurang mempunyai peluang sebesar 4.035 kali tidak puas dibandingkan dengan responden yang pelayanan keperawatan baik.

Hasil penelitian ini sesuai dengan apa yang dikatakan Kepmenkes RI (2006) mendefinisikan pelayanan keperawatan adalah suatu bentuk pelayanan profesional yang merupakan bagian integral dari pelayanan kesehatan yang didasarkan pada ilmu dan kiat keperawatan, berbentuk pelayanan bio-psikososio-spiritual yang komprehensif dan ditujukan kepada individu, keluarga dan masyarakat baik sakit maupun sehat yang mencakup seluruh proses kehidupan manusia. 
Menurut asumsi peneliti dari hasil penelitian dapat diketahui dari 54 yang pelayanan keperawatan kurang terdapat 14 responden yang puas ini dikarenakan olehresponden membandingkan layanan keperawatan yang ia terima di Puskesmas dengan layanan keperawatan di pelayanan kesehatan lain yang cenderung kualitas layanannya lebih rendah dan juga responden menerima bagaimanapun layanan yang di berikan karena responden memaklumi bahwa responden membayar dengan biaya terjangkau bahkan gratis jadi responden tidak menuntut layanan yang lebih baik dari apa yang responden terima.

Sebaliknya dari 41 responden yang pelayanan keperawatan baik terdapat 17 responden yang tidak puas ini disebabkan oleh kurang maksimalnya dalam bekerja sama dengan pasien maupun keluarga pasien.

\section{KESIMPULAN DAN SARAN}

\section{Kesimpulan}

Setelah dilakukan penelitian tentang hubungan pelayanan keperawatan tentang kepuasan pasien rawat inapdi RSUD Bangkinang Kota Tahun 2016 dengan 95 responden, maka dapat diambil kesimpulan sebagai berikut :

1. Diketahui pelayanan keperawatan di RSUD Bangkinang Kota pada kategori kurang 54 responden $(56,8 \%)$

2. Diketahui kepuasan pasien di RSUD Bangkinang Kota pada kategori tidak puas 57 responden $(60 \%)$

3. Diketahui bahwa ada hubungan pelayanan keperawatan dengan kepuasan pasien rawat inap dengan pvalue $0,001(<0,05)$

\section{Saran}

Dari penelitian yang telah dilakukan, penulis memberikan saran-saran sebagai berikut :

\section{Bagi Instansi Pendidikan}

Diharapkan penelitian ini dapat dijadikan data dasar bagi peneliti selanjutnya di bidang kesehatan, khususnya tentang kepuasan pasien dan juga dapat dipergunakan sebagai bahan kepustakaan mengenai kepuasan pasien.

\section{DAFTAR PUSTAKA}

Agustinus LW dkk.(2013). Description of Usual Patient Satisfaction on quality service of inpatient installation of local hospital daya makasar in 2013, bagian MRS Fakultas Kesehatan Masyarakat, Unhas Makasar,

Alamsyah D. (2012). Manajemen pelayanan kesehatan dilengkapi Materi asuransi kesehatan dan mutu pelayanan kesehatan, penerbit Nuha Medika, Yogyakarta

Aritonang dan lerbin, (2005). Kepuasan pelanggan pengukuran dan menganalisa dengan SPSS, penerbit PT Gramedia pustaka Utama, Jakarta.

Arikunto, suharsimi. (2006). Prosedur penelitian suatu pendekatan praktik (edisi revisi VI), Rineka Cipta, Jakarta

Asmuji, (2013), Manajemen keperawatan. Ar-Ruzz Media, Yogyakarta

Azwar Azrul,, (1996), Pengantar administrasi kesehatan edisi ketiga, penerbit binapura aksara.

Bustami, (2011), penjamin mutu pelayanan kesehatan dan akseptabilitasnya, Erlangga, Jakarta.

Dahlan Sopiyudin,, (2004). Statistika untuk kedokteran dan kesehatan, penerbit arkanas, Jakarta.

Depkes, (2002),. Peran dan fungsi perawat, departemen kesehatan republic Indonesia, jakarta

Desmawati dian w,(2013), hubungan layanan keperawatan dengan tingkat kepuasan pasien rawat inap dipuskesmas sembersari labupaten jember. Skripsi. Universitas Jember

Ertanto, w,(2002), hubunagan antara kualitas pelayanan tenaga perawat dengan tingkat kepuasan pasien di ruang rawat inap badan rumah sakit umum DR $H$. soewondo Kendal. Skripsi, Universitas diponegoro

Hasan ali, (2013), marketing dan kasus- kasus pilihan, penerbit center for academic publishing service, Yogyakarta.

Hidayat,A,A, (2008), pengantar konsep dasar keperawatan, penerbit salemba medika, Jakarta. Kepmenkes RI Nomor 828/Menkes/SK/IX/2008. Petunjuk teknis standar pelayanan minimal bidang kesehatan di kabupaten /kota, 2008, Jakarta menkes RI:2008 
Notoadmojo, S, (2010), Metodeologi penelitian kesehatan. Jakarta : Rinika cipta

Marpaung BS, (2009). Gambaran kepuasan pasien terhadap pelatanan keperawatan diruang rawat inap rumah sakit Xyz, (Online), vol 10 no.2, oktober 2010.

Menteri kesehatan republic Indonesia, 2006,kepuasan mentri kesehatan no:279/menkes/sk/iv/2006 tentang pedoman penyelenggaraan upaya keperawatan kesehatan masyarakat dipuskesmas, Jakarta: mentri kesehatan.

Mustofa A, (2008). HUBUNGAN ANTARA PRESEPSI PASIEN TERHADAP DIM ENSI MUTURUMAH SAKIT PELAYANAN KEPERAWATAN DENGAN KEPUASAN PASIEN DIRAWAT INAP RUMAH SAKIT UMUM PKU, MUHAMMADIYAH TEMANGGUNG, VOLUME 1 NO 2 Maret 2008.

Notoadmodjo, S (2010), Metode penelitian kesehatan, jakarta.

Nursalam, (2003Konsep dan penerapan metodologi penelitain ilmu keperawatan penerbit salemba medika, Jakarta, 2014, manajemen keperawatan : aplikasi dalam praktik keperawatan professional edisi 4 salemba medika Jakarta.

Pohan IS (2006), jaminan mutu layanan kesehatan dasar dasar pengertian dan penerapan, penerbit EGC, jakarta.

Purwanto s, (2007) kualitas pelayanana keperawatn, postet on 28 desember 2007 (http:/www file:///E:/kualitas pelayanan keperawatan aritikes\ pisikologi klinis pekembangan dan social htm)

Purwanto EA. Sulistyaastuty DR. (2007) metode penelitian kuantitatif untuk administrasi public dan msalah, masalah social, penerbit gafanesia.

Peasetyo B dan Jamah L.M,(2013). Metode penelitian kuantitafif teori dan aplikasi, $p t$ rqaja gravindo persada, Jakarta.,

Profil rumah sakit umum daerah bangkinang kota kabupaten kampar2016.

Saryono dan mekar dwi anggraini, (2013), p. metode penelitian kuantitafif dan kualitatif dalam bidang kesehatan, nuhamedika, Yogyakarta.

System kesehatan nasional, (2009) bentuk dan cara penyelengaraan pembangunan kesehatan,depertemnen kesehatan republic indonesia, jakarta.

Sugiyono,(2010) statistika untuk penelitain, alfabeta bandung.

Tjiptono, Anastasia dian, (2011) servis manajemen andi Yogyakarta.

Triwibowo, C(2012) perizinan dan akreditasi rumah sakit, sebuah kajian hokum kesehatan, nuhamedika, Yogyakarta

Undang-undangn republic Indonesia no44 tahun 2009 tentang rumah sakit.zarei, et al, 2004, an empirical study of the impact of service quality patient statisfaction in private hospitals, iran, global jurnal of heatlh sciencie 
111| HUBUNGAN PELAYANAN KEPERAWATAN DENGAN KEPUASAN PASIEN RAWAT INAP DI RSUD BANGKINANG KOTA TAHUN 2019 